Working Paper No. 646, 2005

\title{
Sustainable Social Spending
}

by Assar Lindbeck

IUI, The Research Institute of Industrial Economics

P.O. Box 55665

SE-102 15 Stockholm

Sweden 


\title{
Sustainable Social Spending
}

\author{
by Assar Lindbeck*
}

The paper is a revised version of a lecture at the $61^{\text {st }}$ World Congress of the International Institute of Public Finance, Korea, August, 2005.

Institute for International Economic Studies, Stockholm University; and Research Institute of Industrial Economics, Stockholm

Address: Institute for International Economic Studies 10691 Stockholm

Sweden

E-mail: Assar.Lindbeck@,iies.su.se

Phone; +4681630 78; Fax: +468162946 
Abstract

The paper discusses a number of threats to the financial sustainability of social spending: increased internationalization of national economies, gradually higher relative costs of producing a number of human services, the "graying" of the population, slower productivity growth in the private sector, low employment rates, and various types of disincentive effects related to the welfare state itself, including moral hazard. I argue that threats from gradually rising costs of providing human services and disincentive effects of welfare-state arrangements, in particular moral hazard and benefit dependency, are more difficult to deal with than the other threats. I also discuss the choice between ad hoc policy reforms and automatic adjustment mechanisms, delegated to administrative bodies, for dealing with these threats.

JEL Code: E 62, H 31, H 53.

Keywords: Sustainable fiscal policy, Baumol's disease, moral hazard, automatic adjustment mechanisms. 
Oct 6, 2005

\section{Sustainable Social Spending}

Sustainable fiscal policy is usually formulated in terms of the intertemporal budget constraint of the public sector. More concretely, sustainability is defined as a stable debt-to-GDP ratio over some future (possibly infinite) time period - although it is not necessarily the initial ratio that is supposed to be held constant. In today's developed countries, the threats to such sustainability are mainly due to the difficulties in financing "social spending", which today accounts for more than 60 percent of total government expenditures both in EU (unweighted average) and the United States. ${ }^{1} \mathrm{I}$ will therefore restrict the discussion to this type of spending, including both transfer payments and government spending on "human services" such as childcare, preschool training, education, health care, and old-age care. Thus, I will in fact discuss the financial sustainability of the modern welfare state.

The modern welfare state was consolidated during a period - extending approximately from the late 1940 s to the mid-1970s - when the general social and economic conditions in developed countries were highly conducive to the financing of generous social spending. (1) International economic interdependencies were not sufficiently strong to seriously complicate the financing of national welfare-state arrangements. (2) The relative (per unit) production costs of government-provided human services were modest. (3) The demography was favorable for supporting elderly citizens, and fast labor productivity growth generated a rapidly rising tax base. (4) Low unemployment contributed to keep down the number of transfer recipients, relative to the number of taxpayers. Moreover, (5) disincentive effects due to tax 
wedges and moral hazard in benefit systems had probably not yet materialized to any large extent. Indeed, the positive effects on economic efficiency and growth of gradually increased government spending on investment in human capital - such as education, sanitation and basic health care - may very well have dominated over various negative disincentive effects on the national economy. It is also rather generally believed that, up to some (basically unknown) level, social spending has contributed to social and political stability, which may be conducive to economic growth in some interval of social spending; see, for instance, Alesina et al., 1996. For these various reasons, the sustainability of social spending was hardly an issue during this period. ${ }^{2}$

Today, the financial sustainability of the welfare state is threatened by changes in all five dimensions. Some of the threats may be regarded as largely exogenous from the point of view of the welfare-state arrangements. The most obvious example is the internationalization process, but there are also strong exogenous elements behind the rising costs of government-provided human services. Other threats have stronger endogenous elements, in the sense of partly reflecting behavioral responses of private agents to various welfare-state arrangements. Examples are the "unfavorable" demographic development, the fall in productivity growth in the private sector, and the huge increase in prolonged unemployment in Western Europe. The fifth threat on the list above (tax disincentives and moral hazard) is, of course, entirely endogenous by definition. This threat is also the most challenging one, since it raises the possibility that the welfare state might cut off the branch on which it is sitting. Therefore, I will in particular dwell on this particular threat.

I start with the exogenous threats, subsequently shifting to threats with stronger endogenous elements. I concentrate on the situation in Western Europe, where welfare-state arrangements are particularly generous.

\section{Internationalization}

The consequences of the internationalization process for national economic and social policies are an old topic. It was, for instance, intensively discussed and analyzed in the mid-1970s. The internationalization process was then described in terms of a gradual unification of previously segmented national markets; increased export and 
import shares; a faster international transfer of technology; and an increased sensitivity ("elasticity") of the flows of products, capital and labor across national borders in response, for instance, to changes in national policies and cost or price differences across countries; see, for example, Cooper (1968) and Lindbeck (1978).

A main reason why these issues have recently surfaced is, of course, the increased involvement in the world economy of both a number of large developing countries and the former socialist countries in Eastern Europe - all characterized by low laborcost as compared to developed countries. This new feature of the internationalization process probably constitutes the background for the shift of terminology from "internationalization" to "globalization".

The most remarkable effect of the globalization process is that it helps some 2-3 billion people in developing as well as in former socialist countries escape severe poverty in the course of, say, a quarter of a century. ${ }^{3}$ In the political and media discussion in developed countries, less weight has been given to this impressive development than to a number of potentially negative social and economic consequences in the developed countries themselves. Here, I limit the discussion to asserted threats to the financial sustainability of welfare-state arrangements in these countries. Three main channels for such threats seem to have been particularly emphasized: (i) faster international factor price equalization, accompanied by increased structural unemployment; (ii) increased international mobility of a number of tax bases; and (iii) an increased financial strain on various benefit systems because of a large immigration of low-skilled individuals with low labor-force participation. While the first channel reflects an application of standard trade theory (and deficiencies in the functioning of domestic labor markets), the last two channels reflect tax and benefit competition across jurisdictions - with an asserted possibility of a "race to the bottom" of both tax rates and the generosity of various benefits; for an early development of this point, see Break (1967, pp. 23-24).

(i) We would expect the process of international factor-price equalization to be accompanied by faster rates of structural change, plant closures, the outsourcing of labor-intensive activities, and the outflow of real investment to low-wage countries, in particular in labor-intensive sectors. Due to the limited flexibility of various allocative 
mechanisms - including low real and relative wage flexibility and limited labor mobility between production sectors - it is natural to predict increased structural unemployment, reflecting increased mismatches between demand and supply in the labor market. It is also tempting to predict that low-skill groups will be hit particularly hard in terms of real wages and employment opportunities (Feenstra and Hansen, 2005). ${ }^{4}$

What, then, is the empirical evidence that globalization has, in fact, had such effects? Clearly, the estimated rates of "equilibrium unemployment" have increased in many West European countries in recent decades, and the Beveridge curve (expressing the relation between vacancies and unemployment) has shifted to the right - both indicating higher structural unemployment. However, these changes occurred already in the second half of the 1970s and, in particular, in the first half of the 1980s, i.e. before the increased competition from low-wage countries. To a considerable extent, this also holds for the widening of wage differentials in some developed countries. Moreover, various empirical studies indicate that the loss of jobs due to international competition is dwarfed by "ordinary" gross destruction (and gross creation) of jobs as a result of domestic factors. ${ }^{5}$ Indeed, it has even turned out to be difficult to establish that the rate of structural change across production sectors has actually increased during the last two decades (OECD, 2005b, pp. 4-8).

To some extent, the difficulties in finding evidence of large negative effects on domestic labor markets may, however, reflect deficiencies in the empirical studies themselves. For instance, the studies may not have been based on sufficiently disaggregated data. Moreover, the studies may not have fully caught the long-term consequences for the employment situation of contemporary shifts in investment from developed to developing countries. Therefore, increased internationalization may in a long-term perspective make it more difficult than otherwise to reduce structural unemployment or raise the relative wages of low-skilled workers

Another reason why it has turned out to be difficult to agree about the labor market consequences of the contemporary internationalization of national economies is that the situation differs considerably across developed countries. For instance, it is likely that the German-speaking countries on the European continent feel a particularly 
strong pitch from low-wage competition because of their geographical and cultural proximity to previous socialist countries in Eastern Europe, where labor costs are low while the general education level is often rather high (Becker et al., 2005; Marin, 2004; Sinn, 2004). This observation underscores the importance of the distinction between global and regional internationalization. It also illustrates the possibility that developed countries may experience increased competition also in sectors using highly educated labor.

To sum up: it has turned out to be difficult to confirm the (reasonable) hypothesis that the contemporary internationalization process has resulted in a strongly increased strain on the labor markets in developed countries, with tendencies to higher structural unemployment (than otherwise), and related financial difficulties for welfare-state arrangements. Nevertheless, it would be unwise to rule out the possibility of considerable effects of this type. Since increased economic openness also seems to contribute to macroeconomic instability, we may expect that the political demand for income protection will increase with higher openness - a point emphasized by Cameron (1978) and Rodrik (1998), for instance.

(ii) Turning to the second channel by which the internationalization process may threaten the financial sustainability of social spending, it is obviously true that a number of tax bases have gradually become more internationally mobile. Capital income is the most obvious example. But since capital taxes constitute a rather modest fraction of total government revenues in countries with advanced welfare-state arrangements, this particular threat seems to be fairly modest. ${ }^{6}$ It has, however, become more difficult for national governments to redistribute income from the highest income percentiles, for which capital income is important, to other percentiles. These difficulties are illustrated by recent reductions in capital income tax rates in many countries.

International mobility is much smaller for human capital (high-skill labor): individuals are culturally and emotionally more closely tied to specific nations than is capital! Family relations also constrain individuals' permanent shifts of country of residence. Moreover, when individuals choose their country of residence - rather than the country for their capital assets - they presumably also look at the prospective 
benefits to themselves of government spending, directly via social insurance and taxfinanced human services, as well as indirectly via the general social and political environment in the country (externalities). In reality, the net flow of human capital across developed countries is quite limited today. Hence, so far there is not much evidence that international mobility of highly educated individuals is a serious threat to the financial sustainability of social spending in developed countries. The situation may, of course, change in the future; indeed, there is already some tendency among national governments to make selective tax concessions for foreign specialists.

(iii) Let us turn to the immigration of low-skilled workers to developed countries. The problem here is that these countries have turned out to be rather unsuccessful in integrating such immigrants in domestic labor markets, partly because of strongly regulated wages for low-skill workers. As a result, although such immigration may "improve" the demography of the population as a whole, the fraction of individuals living off welfare-state benefits may very well increase. However, it is then the malfunctioning of the domestic labor market that creates the threat to the financial sustainability of welfare-state arrangements - rather than immigration per se.

\section{The productivity dilemma for human services ("Baumol's Cost Disease”)}

Another largely exogenous threat to the financial sustainability of the welfare state comes from the productivity developments for human services, in particular childcare, pre-school training, education, and old-age care. At the same time as the demand for such services tends to go up with higher per capita income and increased female labor force participation, the relative production costs of such services rise over time. A well-known reason is that it is difficult to rationalize labor-intensive production of this type by more capital and better technology, while wages broadly follow those in sectors with faster productivity growth. This is, of course, Baumol's (1967) celebrated “cost disease” for labor-intensive services, or Baumol’s Law.

As a result of these mechanisms, an increased consumption of tax-financed human services would be expected to require gradually higher tax rates - possibly until the top of the Laffer curve has been reached, when further tax financing becomes technically impossible. This inference can be more precisely formulated in the context of a two-sector model, where labor is the only input and where there is only one type 
of tax, represented by an income tax rate to balance the budget. In this case, the tax rate must be raised as long as an increasing share of the total labor force is allocated to produce human services - that is, as long as we want to increase the consumption of such services faster than the rate of increase of labor productivity in this sector; see the Appendix. In the special case when the production of human services is a constant share of aggregate output, it is necessary to raise the tax rate at a speed determined by the difference in the rate of productivity growth between the two sectors (Appendix). ${ }^{7}$ The tax rate must, of course, be raised even faster, if we want to increase the production of human services more than that of other products.

Several factors might retard such a process of gradually higher tax rates to finance human services: lagging relative wages in this sector; ${ }^{8}$ an increased employment rate in the economy as a whole; or sufficiently large cuts in other types of government spending, such as infrastructure investment, defense or transfer programs ${ }^{9}$. Such counteracting policy actions can, however, not go on forever and hence, they can only temporarily reduce the need for tax rate increases. The financing problem does not disappear as long as productivity growth is slower for tax-financed human services than for other products.

The gap in productivity growth between sectors might, however, be reduced by allowing competition from private producers, since this is likely to boost productivity in the public sector. As a result, it would take longer time for Baumol's disease to be "deadly". It would, however, be highly optimistic to assume that the gap in productivity growth could be permanently eliminated in this way.

In the political discussion, it is often also asserted that the financing of subsidized (or government provided) human services would be facilitated by a faster productivity growth in the private sector, since the tax base would then expand more quickly. This argument builds on a fallacy, however. The intuitive reason is that a more rapid rate of productivity growth, and related real wage growth, in other sectors would, in fact, raise the wage costs for human services at the same rate as the tax base (still assuming the same path of wage rates in both sectors); see the Appendix. ${ }^{10}$ 
The problems are somewhat different for health care than for childcare, education and old-age care. While productivity growth tends to be slow also in certain parts of health care, in other parts it has been, and is likely to continue to be, quite fast as a result of new medicines and improved operation technology. ${ }^{11}$ However, as pointed out by Baumol et al. (1985), this does not solve the problem in a very long-term perspective. The reason is that the labor-intensive part of such sectors would gradually account for a rising share of total expenditures in those sectors (just because of the slow rate of productivity growth for that part of the sector). In the long run, we are therefore (asymptotically) back to the predictions of Baumol's Law, also in the case of human services for which parts of the production activity enjoys a fast productivity growth rate. Moreover, as we know, the fast productivity growth in the "pure" medical part of health care does not only result in lower costs of treating the same health problems as earlier. It also increases the possibilities of treating health problems that could not be dealt with earlier. It is unavoidable that such technological improvements dramatically boost the demand for health care (at a given path of incomes and prices). For these reasons, health care will, in fact, be exposed to similar financing problems as other human services, although partly for different reasons.

To avoid indefinitely increasing tax distortions, countries where only tax-financing of human services is accepted today will sooner or later be forced to consider complementary sources for financing human services, or to limit the expansion of consumption of human services. I refer to service fees, voluntary or mandatory (actuarial) insurance, and mandatory saving accounts with special drawing rights for the consumption of human services (such as in Singapore and Malaysia). Since such financial arrangements, in contrast to income taxes, are not progressive, these countries may be confronted with a choice between more (or better) human services (financed via new sources), on the one hand, and a stagnant volume of more evenly distributed (tax-financed) services, on the other.

This situation may be compared with the case when human services are provided in private markets without government subsidies. Then, the consumption of such services will continue to increase, as long as the positive demand effects in connection with a gradually higher per capita income (and other demand-boosting factors) are stronger than the negative price effects on demand. Therefore, we may encounter the 
somewhat paradoxical situation that countries insisting on tax-financing human services, partly for the purpose of stimulating their consumption, may have to accept smaller aggregate consumption of such services in the future (to avoid gradually increasing tax distortions) than countries where the services are bought in nonsubsidized markets.

Thus, it may be a good idea for the authorities in countries with tax-financing of human services to already now start considering how to introduce complementary financing methods, without undesired distributional consequences. One possibility would be to use progressive fees for such services (at least above some income level for the individual) as an alternative to higher tax rates. One problem would then, of course, be that the marginal tax rates would be raised "by a backdoor" - with related incentive problems. However, in the case of medical care and old-age care, this disincentive effect might be smaller than with conventional tax financing, since each individual's future need for medical services and old-age care is highly stochastic. It is only with a certain (modest) probability that, in the future, the individual will be confronted with high expenditures for such care services and hence, in fact be exposed to high expected (implicit) marginal tax rates during her working life.

\section{Demographic Changes and Slower Productivity Growth in the Private Sector} Although the "graying" of the population is largely an exogenous disturbance for welfare-state arrangements, it may also to some extent be regarded as an endogenous adjustment to the welfare state itself. One example is that higher pensions and improved health care of the elderly have contributed to raise their life expectancy. Another example is that such arrangements make it less important for the individual to have children - a point emphasized by Hans-Werner Sinn (1999).

Since the graying of the population simultaneously boosts social spending (in particular, for pensions, health care, and old-age care) and retards the growth of the tax base, it is natural that the sustainability of welfare-state arrangements is threatened. ${ }^{12}$ The consequences for the financial sustainability of social spending of the slowdown of labor productivity growth since the mid-1970s are a more complex issue. To the extent that the benefit levels in the social insurance systems are not fully downward adjusted in proportion to slower productivity growth and hence, to the 
slower growth of the aggregate tax base, the financial position of social spending is bound to be damaged. ${ }^{13}$

It is difficult to solve these problems "at the source", i. e., by improved demography or faster productivity growth. It takes about a quarter of a century before higher birth rates affect the size of the labor force. Moreover, it is not easy for the government to control the age composition, the qualifications and the employment rates of immigrants. To the extent that governments have taken actions to mitigate the emerging financing problems for welfare-state arrangements as a result of changes in demography or productivity growth in the private sector, these have instead taken the form of ad hoc increases in social-security fees (or taxes) and reductions in the generosity of the benefits (including a higher statutory retirement age). An alternative could be to delegate corrective measures to some administrative body according to a predetermined automatic rule - mimicking the functioning of actuarially fair private income insurance systems. In other words, benefits and/or contributions might be made contingent on developments in demography and productivity growth alternatively, simply on the development of the financial position of specific social insurance programs. This would have the advantage that politicians would not from time to time have to take unpopular discretionary decisions themselves to guarantee the financial stability of the social-insurance systems. The new defined-contribution paygo pension system in Sweden (introduced in the late 1990s) is an illustration of this, since pension benefits are automatically adjusted downwards in response to higher life expectancy and slower real wage growth for contributing workers. ${ }^{14}$

One disadvantage of such automatic adjustment of the pension benefits is, of course, that there will be less ex ante insurance: citizens are no longer promised a specific pension benefit level - not even a specific replacement rate (a fixed ratio of benefits to recent earnings). But how valuable is it, really, for the individual to be promised unconditional pension benefits (or a fixed replacement rate) in the future if the government may, in fact, not be able to finance the promises? Might it be enough for the individual to know his state-contingent pensions benefit in advance - and be confident that the system is financially stable? The individual could then himself voluntary save or sign into insurance contracts as complements to the mandatory social insurance systems. 
Would it be useful to introduce similar automatic adjustment mechanisms in other social insurance systems? That could, for instance, mean automatic cuts in per capita unemployment benefits if the number of unemployed workers increases, and automatic cuts in sick-pay and early retirement pensions in response to higher numbers of individuals living on sick-pay and early retirement pensions. In principle, we could also conceive of automatic adjustments of such benefits in response to changes in real wage growth and hence, indirectly to changes in labor productivity growth among contemporary employees. It is an understatement that reforms along these lines may create serious political controversy. ${ }^{15}$

Another complication with an automatic adjustment mechanisms is, of course, that the rules of these mechanisms may, in fact, not be fixed. For instance, if the operation of an automatic mechanism were to result in substantial future income losses for some specific social groups, irresistible political demands for an overhaul of the rules may emerge. Automatic rules might be more stable if the income risks are shared rather evenly in some predetermined proportions between different population groups (such as between retirees and the working-age population). This would be in contrast to the new Swedish pension system, where the entire adjustment burden falls on the pensioners.

Hence, it is difficult to evaluate the gain from shifting to an automatic adjustment mechanism, rather than continuing to rely on discretionary ad hoc policy changes. Personally, I believe such automatic adjustments to be at least worth considering just to reduce the burden on politicians from having to take unpopular discretionary decisions at times.

\section{The threat from lower employment rates}

The financial position of social arrangements in Western Europe has, of course, also been harmed by the rise in prolonged unemployment - a combined effect of exogenous factors and endogenous adjustments of individual behavior to welfare-state arrangements. The consequences for the sustainability of social spending are rather similar to the effects of recent demographic development, in the sense that transfer payments increase at the same time as the tax base is harmed. 
The two most common explanations among economists of high and prolonged unemployment in Western Europe are probably (i) an increase in the "equilibrium unemployment rate" ${ }^{16}$ and (ii) strong unemployment persistence after negative macroeconomic shocks. ${ }^{17}$ One reason for believing that not only the former but also the latter explanation is important in Western Europe is that estimated equilibrium unemployment rates have, in fact, closely "shadowed" the actual unemployment rate. Econometric studies claiming to estimate the rise in equilibrium unemployment may therefore, to a considerable extent, simply reflect a combination of a series of unemployment-creating macroeconomic shocks (starting in the mid-1970s) and persistence mechanisms. Unemployment persistence may, however, be transformed into a higher equilibrium unemployment rate after a while. One mechanism through which this might occur is that social norms against living off unemployment benefits, or other benefit systems, may recede when many others live that way (Lindbeck, 1995).

Adequate policy recommendations differ in important respects across these two partly competing, partly complementary - explanations of high prolonged unemployment. When it comes to structural reforms (largely "supply-side policies"), several policy recommendations coincide, however. Obvious examples are subsidized labor-market exchange, subsidized labor-market training of "outsiders", and employment subsidies for low-skilled workers. A rather successful example of the last mentioned approach, although rather limited in scope, is "in-work benefits" in the US and the UK (formally "tax credits"), designed to increase the labor supply among lowskilled individuals. ${ }^{18}$ In countries with relatively high and regulated wages for lowskilled workers, labor demand rather than labor supply may be the problem, however. In this case, employment subsidies paid to employers hiring such workers may be more adequate than "in-work benefits" paid to workers. ${ }^{19}$ The consequences of such subsidies for the financial position of the government are uncertain. Although the tax base, and hence tax revenues, is likely to increase, the net effects on aggregate government spending are uncertain, since one type of government spending (benefits for non-work) are replaced by other types (subsidies for work). Even if the net effect on the government's budget balance of such policies would, in reality, turn out to be negative, the deterioration is likely to be modest. Indeed, the budget balance would 
even improve if work subsidies were confined to individuals getting off benefit systems, such as unemployment benefits, sick pay or early retirement pensions (provided that the subsidies were lower than the benefit rates).

Some other types of labor market policies also tend to improve the government financial position. The most obvious example is reduced unemployment benefits or stricter controls of the beneficiaries - although such policies would harm workers not able to get jobs even when trying hard. Some off-budget labor-market policy measures would also improve the government's budget position, an obvious example being lower minimum wages (when these are binding), which tend to boost the tax base via higher employment - although this improvement occurs at the cost of individuals initially living on minimum wages.

Moreover, if we emphasize persistence mechanisms and not just increased equilibrium unemployment, a softening of the job-security legislation would also boost the employment level. While the effect of such reforms on the equilibrium unemployment rate is uncertain (both the firing and hiring of workers would increase), they tend to reduce the persistence of (un)employment - regardless of whether the existing employment level is high or low. According to the insideroutsider theory (Lindbeck and Snower, 1988), a reduction in hiring and firing costs would also indirectly improve the employment prospects of outsiders via the consequences for wage formation, since the market powers of insiders would be reduced. These powers may also be reduced by removing (or softening) existing legislation that widens the coverage of collective wage agreements to encompass nonorganized workers. A shift in wage bargaining to the level of individual firms may also help boost the demand for low-skilled workers, since the flexibility of relative wages is then likely to increase (if this is not prevented by minimum-wage legislation). Since such a shift is likely to reduce the relative wages of low-skilled workers, the case for "in-work benefits" à la US and UK, rather than wage subsidies paid to firms, would then be strengthened. All such non-budget supply-side policies would be expected to improve the government's financial position.

The consequences for the long-term sustainability of government spending of demand management in product markets in recessions are more complex. If persistence 
mechanisms are the main problem, expansionary demand management in product markets becomes useful, not only to counteract unemployment-creating macroeconomic shocks, but also to speed up the return to lower unemployment afterwards. ${ }^{20}$ Expansionary demand management in product markets is less useful if the problem is a high equilibrium unemployment rate; such policies are then only useful for keeping the unemployment rate as close to the equilibrium rate as possible. The classical problem with expansionary aggregate fiscal policy in recessions is, of course, that it may be politically impossible to reverse the ensuing budget deficits in a subsequent boom, with galloping public debt as a conceivable long-run result. There might also be a risk that politicians will regard expansionary demand management in product markets as a substitute rather than a complement to structural reforms of the national economy. As soon as we try to "endogenize" politicians, there is no "riskfree" economic policy, however.

\section{Economic incentives, moral hazard and social norms}

The consequences of welfare-state spending for economic incentives do not only depend on the aggregate level of such spending, and the aggregate level of taxes and fees financing the spending. They also crucially depend on the details of both the welfare-state arrangements and the way these are financed. Therefore, it is artificial to study the effects of higher taxes in isolation, hence without concern for the effects of related changes in government spending. For instance, the negative substitution effects of higher taxes on labor supply and saving would be counteracted by positive income effects if the tax revenues finance benefits to individuals who cannot work under any circumstances (due to bad health or old age). ${ }^{21}$ Indeed, in this special case, there may be no net effect at all, since the income and substitution effects are often of about the same size. The negative substitution effects themselves would also be mitigated if there were a (positive) link between the individual's contributions (taxes or fees) and his/her expected future benefits, as in "quasi-actuarial" social insurance systems. Moreover, the negative substitution effects on labor supply would be counteracted by positive cross substitution effects if the tax revenues were used to finance services that are substitutes to the home-production of such services and hence, complements to work in the open labor market (Lindbeck, 1980). Obvious examples are childcare and old-age care. 
Empirical studies suggest that the effects of changes in tax rates on hours of work (for individuals actually working) are rather modest in most developed countries. The disincentive effects are stronger if we also take proper account of marginal adjustments in other dimensions of individual economic behavior-including investment in human capital, intensity of work, ambitions to get promoted, the willingness to shift to new jobs, saving, investment in real capital assets, etc. ${ }^{22}$ However, the complexity of the issue has, so far, made it impossible to come up with non-controversial estimates of such effects.

Without questioning the importance of marginal adjustments of individuals in the work force, when all such dimensions are considered, I will instead emphasize the consequences for labor force participation. Empirical studies indicate that such adjustments are much stronger than marginal adjustments of hours of work; see, for instance, the surveys in Heckman (1993), Blundell and MaCurdy (1999), and Browning et al. (1999). In other words, when it comes to labor supply, individuals' adjustments on the "extensive margin" (work or non-work) seem to be more much more important than adjustments on "the intensive margin" (hours of work). As a result, the marginal costs of public funds (MCF) are much larger when we take account of adjustments in labor force participation and not just hours of work. ${ }^{23}$

What is of importance when including adjustments also on the extensive margin is, of course, not only the marginal tax rate but also the relation between average after-tax earnings and the generosity of (after-tax) benefits. This has been understood for a long time in the labor market literature when analyzing "poverty traps". It is time to take today's "benefit traps" for a wide range of individuals in low and middle income brackets seriously, due to the interplay of taxes and social-insurance benefits (unemployment insurance, sick-pay insurance, early retirement pensions, etc.).

Today, several countries in Western Europe offer replacement rates in various social insurance systems amounting to as much as $75-95$ per cent for low and middle income groups of citizens ${ }^{24}$ - if we take account of occupational benefits on top of government-provided benefits. Indeed, in some countries, large population groups hardly conceive any income difference at all between earnings from work and social- 
insurance benefits, in particular when all financial costs connected with work are considered. $^{25}$

Indeed, in Western Europe, about a fifth of the population of working age (25-64) today live on benefits of various types - besides unemployment benefits and labor market programs, mainly social assistance, sick-pay insurance, and early retirement pensions (OECD Employment Outlook, 2003, pp. 188-190). It is easily understood that financing this high benefit dependency is expensive - in addition to the financing of the large number of individuals above the statutory retirement age, constituting 23 per cent of the number of individuals of working age in Western Europe, and is expected to increase rapidly (EU-19; see footnote 11).

Hence, the welfare state poses a basic dilemma. We want to be generous to individuals who are sick, unemployed, or unable to work before the statutory retirement age, without its being their own fault. But such generosity opens the doors to moral hazard, when some individuals find that the economic reward for work does not match the physical or mental discomfort of attending a job. Due to asymmetric information between the insurer and the insured, the latter can easily generate insurance outcomes at their own discretion to pursue more leisure, household work, or working in the "shadow economy" - at very low opportunity costs for themselves. We may say that some individuals simply "redefine" - for themselves as well as for the social insurance administrators - the discomfort making them eligible for benefits of various types (Lindbeck 1995; Lindbeck and Persson, 2005). In today's advanced welfare states, the choice between labor force participation and benefit dependency is largely an issue of moral hazard.

Quantitatively important illustrations of benefit dependency and hence, moral hazard in Western Europe today, besides individuals living off unemployment benefits, are the large number of early-retirees, for instance, in Belgium, Italy and the Netherlands and the high sickness absence, for instance, in the Netherlands, Norway and Sweden in spite of relatively good health in these countries (not least in the last three) according to available health statistics. 
As indicated in my earlier discussion of unemployment, moral hazard becomes particularly serious if social norms in favor of work, or against living on benefits, gradually erode over time, possibly as individuals notice that others already finance their consumption this way (Lindbeck, 1995; Lindbeck, Nyberg, and Weibull, 1999). If this hypothesis is correct, moral hazard becomes more important in the long term than in the short term. More specifically, in the long run, endogenous changes in social norms towards work and/or benefit dependency create a "social multiplier" on moral hazard (Lindbeck and Persson, 2005).

Benefit traps depend, of course, on the difference between the individual's total after tax earnings and benefits rather than the marginal returns to work. Thus, individuals' adjustment to benefit systems largely take place at the "extensive margin" (work or non-work), rather than at the "intensive margin" (hours of work among those actually employed): usually, benefits are only obtained if the individual altogether abstains from work (such as in the case of long-term unemployment, long-term sickness and early retirement). This may be a reason why empirical studies indicate higher elasticities of labor supply (in terms of total hours of work) with respect to the generosity of benefits than with respect to marginal tax rates; see, for instance, the survey in Krueger and Meyer (2002). By contrast, marginal tax wedges are more likely to harm labor productivity and economic growth, as a result of the influence on intensity of work, the allocation of labor, and investment in human capital.

The hypothesis that moral hazard is today a serious problem, and that it gradually builds up as a result of endogenous changes in social norms, has so far not been rigorously tested. Thus, it is still just a hypothesis. However, it seems consistent with causal observation (Lindbeck and Nyberg, 2005). For instance, benefit dependency did not increase to any larger extent from the early 1950s to the later 1970s in Western Europe, when the generosity and coverage of social benefits increased considerably. Such dependency did, however, increase in subsequent decades, in spite of a more or less constant generosity of benefits during that period. ${ }^{26}$ Indeed, the percentage of beneficiaries of working age in the EU went up from 15 in 1980 to 20 in 1999 (OECD Employment Outlook (2003, pp. 188-190). A more convincing illustration might be that similar time lags of benefit dependency are observed after detailed changes in specific benefit systems - undertaken at different points in time in 
different countries (Lindbeck and Nyberg, 2005). Naturally, such aggregate time series are "smoking guns", rather than empirical tests.

Our knowledge about the psychological mechanisms behind hypothesized changes in social norms concerning work and benefit dependency is also still modest. However, attitude studies in Sweden suggest that a considerable fraction of individuals today are prepared to call in sick, without being sick in a traditional medical sense - e.g., when feeling tired or experiencing discomfort in going to work because of a dislike for their work or their bosses, or conflicts within the family. ${ }^{27}$ Moreover, at least one Dutch attitude study indicates that a non-negligible number of individuals believe that they have legitimate "rights" to live on tax-financed benefits, even if they are able to work and also get a job (Engbersen et al., 1993). There is also considerable evidence of direct benefit fraud, which is sometimes difficult to distinguish from moral hazard. ${ }^{28}$

Since social norms presumably often emerge from social interaction among individuals in their own neighborhoods, or the plants where they work, we may expect strong local variations in the strength of such norms. Indeed, even after accounting for the influence of a large number of socio-economic variables, there are huge differences in sickness absence across firms and municipalities in Sweden. It has been suggested that these differences may reflect such local variations in social norms. ${ }^{29}$ More empirical research is certainly needed on this issue.

The standard recommendation for mitigating moral hazard is, of course, some combination of stronger economic incentives and stiffer controls. Indeed, the recommended incentive devices tend to be the same in all benefit systems: lower replacement rates and more waiting days. The control devises differ across benefit systems, however. While, the controls in sick pay insurance and early retirement pensions employ an examination of the individual's health condition (such as doctors' certificates) ${ }^{30}$, rehabilitation, visits to the individual's home and controls at the work place, controls in the unemployment insurance system instead usually rely on tests of the individual's willingness to work (and related threats of the withdrawal of payments). ${ }^{31}$ 
It is not likely that politicians anticipated serious moral hazard problems and lagged changes in social norms, when they constructed today's benefit systems. Therefore, it is reasonable to assume that the systems have became more generous than if politicians had correctly anticipated the long-term consequences. In this sense, the size of welfare-state spending may have "overshoot" the planned levels. When politicians discover such overshooting, they are likely to conclude that retreats from the generous benefit rules are required. However, they are bound to find that such retreats are painful for the general public and politically costly for themselves. Although the previously mentioned "social multiplier" may work also in the case of benefit cuts, we would expect that, once more, individuals only adjust after time lags. Governments anxious to quickly solve the financing problems for the welfare may, therefore, have to cut benefits quite drastically.

There are well known problems with all these methods for fighting moral hazard. While lower replacement rates and longer waiting periods necessarily harm individuals actually being too sick to go to work, losses of personal integrity are unavoidable in the case of tighter controls. Moreover, in the case of sick-pay insurance and early-pension insurance, the efficiency of controls is limited by tendencies among benefit applicants to refer to health problems that are difficult, or even impossible, for physicians to check. Well-known examples are skeletonmuscular problems and diffuse mental problems (fatigue and "burn out" phenomena) - indeed, types of (asserted) health defects that today dominate when individuals call in sick or apply for early retirement. A third possibility to fight moral hazard might be propaganda campaigns by the authorities to restore social norms against misuse or "overuse" of benefit systems. It is an open question if, and to what extent, such campaigns would be successful in a long-term perspective. ${ }^{32}$

In reality, we would expect governments to try combinations of these methods to prevent moral hazard from seriously harming the financial sustainability of social insurance programs - the day governments, and the electorate, believe the problem to be severe. 


\section{Concluding Remarks}

Different contemporary threats to the financial sustainability of social spending require different counter-measures. Threats from globalization may force national governments to choose between protectionism, international policy coordination, and measures to increase the flexibility in the domestic economy - although I have argued that these particular threats have probably been exaggerated in the general discussion. "Baumol's disease" will sooner or late make it necessary to add new methods of financing human services to existing tax-financing - if governments want to satisfy the gradually increased demand for such services when there is an increase in real income and female labor-force participation. To deal with problems created by the demographic transition (the "graying" of the population), some combination of higher effective retirement age, higher contributions, and lower benefits in the pension system, including less generous rules for early retirement, will be necessary. A solution to the unemployment problem, in particular in Europe, would require a combination of improved aggregate demand management and structural reforms reducing the equilibrium unemployment rate and unemployment persistence. Moreover, to mitigate tax disincentives and moral hazard ("leveraged" by changes in social norms), the basic choice is, of course, between less generous benefits and tighter controls of individuals claiming benefits - or rather a combination of these actions. Clearly, in each case, severe political difficulties, social costs, and distributional conflicts are unavoidable.

I have also argued that the financial sustainability of social spending may be improved by a shift from discretionary ad hoc policies to automatic adjustment mechanisms in specific social insurance systems. An alternative, or complementary, approach might be to opt for fixed rules concerning the aggregate government budget. Two quite different methods may then be identified. One, which in a "Buchanian" fashion (e. g., Buchanan, 1987) may be called "constitutional", would be to opt for a budget process mitigating tendencies to "irresponsible" spending - such as strong powers for the Treasury as compared to the "spending department", a powerful ("coordinating") budget committee in parliament, and/or a recursive budget process where total spending is decided in a first step, before funds are allocated to different types of spending. ${ }^{33}$ 
The other approach would be to restrict the aggregate content of the budget, for instance by a predetermined ceiling on aggregate spending, or requirements about the size of the budget deficit. It has, however, turned out that governments often find ways of circumventing such rules. Moreover, such restrictions easily conflict with (reasonable) stabilization policy ambitions. Indeed, if the rules make it impossible to avoid high and persistent unemployment, the basic purpose of improving the financial sustainability of government spending by such rules may fail, since high unemployment will automatically harm the government's financial position.

Similar problems arise if domestic budget policies are constrained by internationally agreed restrictions on national budgets, such as the Stability and Growth Pact (SGP) of the EU. ${ }^{34}$ It has also turned out that such internationally imposed rules, and related punishment mechanisms, are often difficult to implement because of the "political drama" that emerges when a country exceeds the threshold budget deficit and, as a result, is supposed to be punished as a lawbreaker. Naturally, this is one background for various proposals, and actual attempts, to soften the rules, or their implementation.

A more radical reform of the SGP would be to opt for "Pigouvian taxes" in some proportion to the budget deficit of an individual country (to limit negative externalities on other countries), instead of relying on punishment in the form of fines when an arbitrarily set threshold for the budget deficit is exceeded. With Pigouvian taxes, a country feeling a particular need to boost aggregate demand for stabilizationpolicy purposes could then "buy" permission for pursuing such policies. Much "political drama" could be avoided by such a shift from the "legalistic" perspective adopted in the SGP (with punishment for the breaking of rules) to an "economictheory" based perspective, with corrective taxes to deal with externalities caused by spillover effects on other EU countries of large budget deficits (Lindbeck and Niepelt, 2005). ${ }^{35}$

If automatic adjustment mechanisms, procedural rules, or (national or international) restrictions on the content of domestic budgets all fail, what remains for politicians is to stick to "improvisations". So far, there are no systematic studies of conditions under which such improvisations are successful. A casual look at recent experiences 
suggests that it may be difficult to find institutional explanations of successful, and less successful, countries in this respect. For instance, two countries with majority voting and majority governments, New Zeeland and the UK, made some retreats in the generosity of welfare-state spending in the 1980s. However, countries with proportional voting and multiparty systems, such as Denmark and the Netherlands, made similar retreats at about the same time, as did Finland and Sweden in the 1990s.

However, it is often suggested that acute economic crises often make it politically possible to cut down social spending that threatens to become financially unsustainable in a long-term perspective - regardless of the political constitutions. Once more, there has not been much systematic research on this issue. It is, however, interesting to note that all "retreat countries" mentioned above initiated their retreats in connection with severe, and in some cases acute, national economic problems such as slow per-capita income growth, high and/or rapidly rising unemployment, or a rapidly rising debt-to-GDP ratio. ${ }^{36}$ If this generalization holds, we would expect recurring periods of financing problems followed by ad hoc spending cuts and/or tax increases, rather than a smooth path of sustainable social spending. 


\section{Appendix: the productivity dilemma for human services.}

To highlight the consequences of Baumol's Law for the provision and financing of human services, I assume a stylized two-sector economy, where the public sector produces an aggregate human service and the private sector another (aggregate) good. Homogenous labor is the only input in both sectors. Let us denote labor input and service output in the public sector by $L_{1}$ and $Q_{1}$, respectively, and labor input and output in the private sector by $L_{2}$ and $Q_{2}$. I also assume labor productivity to increase at the rate $\rho$ in the public sector and at the rate $r$ in the private sector with $r>\rho$. Wages in both sectors (W) are assumed to increase at the same rate as productivity growth in the private sector. Assuming the labor productivity parameters $a$ and $b$, and denoting time by $t$, we have

$$
\begin{aligned}
& Q_{1 t}=a e^{\rho t} L_{1 t} \\
& Q_{2 t}=b e^{r t} L_{2 t} \\
& W_{t}=W e^{r t}
\end{aligned}
$$

The development of unit costs $C_{1}$ and $C_{2}$ in the two sectors may then be written as

$$
\begin{aligned}
& C_{1 t}=W_{t} L_{1 t} / Q_{1 t}=W e^{(r-\rho) t} / a \\
& C_{2 t}=W_{t} L_{2 t} / Q_{2 t}=W / b
\end{aligned}
$$

Hence, while unit costs are constant in the private sector, they rise gradually, and indefinitely, in the public sector at a rate determined by the difference between $r$ and $\rho$ - an expression of "Baumol's cost disease" for labor-intensive services.

The development of total costs is

$$
\begin{aligned}
& C_{1 t} Q_{1 t}=W e^{(r-\rho) t} / a \cdot\left(a e^{\rho t} L_{1 t}\right)=W e^{r t} L_{1 t} \\
& C_{2 t} Q_{2 t}=W / b\left(b e^{r t} L_{2 t}\right)=W e^{r t} L_{2 t} .
\end{aligned}
$$

Assuming a balanced budget for human services, the tax rate $(\tau)$ must be equal to the share of public-sector costs relative to the aggregate national economy 


$$
\tau=\frac{C_{1 t} Q_{1 t}}{C_{1 t} Q_{1 t}+C_{2 t} Q_{2 t}}=\frac{W e^{r t} L_{1 t}}{W e^{r t} L_{1 t}+W e^{r t} L_{2 t}}=\frac{L_{1 t}}{L_{1 t}+L_{2 t}}
$$

Hence, the tax rate is determined by the fraction of total labor employed in the public sector. It must be gradually raised as long as this fraction increases, i. e., as long as the production of tax-financed human services grow faster than the rate of productivity growth in their production.

Let us rewrite (8) in terms of output variables instead of labor inputs (hence, substituting from (6) and (7)),

$$
\tau=\frac{Q_{1 t} W e^{(r-\rho) t} / a}{Q_{1 t} W e^{(r-\rho) t} / a+Q_{2 t} W / b}=\frac{1}{1+\frac{a Q_{2 t}}{b Q_{1 t}} e^{(\rho-r) t}} .
$$

Let us look at the special case when public-sector output is kept as a constant share of the national economy and hence, $Q_{2 t} / Q_{1 t}$ is constant (for instance, as a result appropriately increasing government subsidies). In this case, the tax rate must be raised over time at a rate determined by the difference in the rate of productivity growth between the two sectors.

In principle, the outbreak of Baumol's disease could be "slowed down" if it were possible to increase the rate of productivity growth in the public sector, relative to the rest of the economy - as seen from equation ( $\left.8^{\prime}\right)$. By contrast, faster productivity growth for the private good would not help. Indeed, for a given ratio $Q_{2 t} / Q_{1 t}$, the tax rate would have to be raised at a rate determined by the difference between $r$ and $\rho$. 


\section{References}

Alko, Juha, Jukka Lassila, and Tarmo Valkonen. (2005). "Demographic Uncertainty and the Evolution of Sustainability of Pensions Systems". In Robert Holzner, and Ed Palmer (eds.), Non-Profit Defined Contribution (NDC) Pension Schemes: Concepts, Issues, Implementation, Prospects, Washington, DC: The World Bank.

Alesina, Alberto, et al. (1996). "Political Instability and Economic Growth”, Journal of Economic Growth 2, 189-213.

Baumol, William. (1967). "Macroeconomics of Unbalanced Growth: The Anatomy of Urban Crisis", American Economic Review, 57, 415-265.

Baumol, William, Sue Anne Betey Blackman, and Edward N. Wolff. (1985).

"Unbalanced Growth Revisited: Asymptotic Stagnancy and New Evidence", American Economic Review, 75(4), 806-817.

Becker, Sascha O., et al. (2005). "Location Choice and Employment Decisions: A Comparison of German and Swedish Multinationals", mimeo, June.

Blanchard, Olivier, and J. Wolfers. (2000). "The Role of Shocks and Institutions in the Rise of European Unemployment: the Aggregate Evidence”, Economic Journal, 110, C1-33.

Break, George. (1967). Intergovernmental Fiscal Relations in the United States, Washington, DC: Brookings Institution.

Blundell, R. W. and T. MaCurdy (1999), "Labor Supply: A Review of Alternative Approaches", in O. Ashenfelter and D. Card (eds.), $\underline{\text { Handbook of Labor }}$ Economics vol. 3A, Amsterdam: Elsevier Science B.V. 
Browning, M., L. P. Hansen, and J. J. Heckman, 1999. "Micro Data and General Equilibrium Models", in J. B. Taylor and M. Woodford (eds.) $\underline{\text { Handbook of }}$ Macroeconomics, vol. 1A, Amsterdam: Elsevier Science B.V.

Buchanan, James. (1987). “The Constitution of Economic Policy”, American Economic Review, 77(3), 243-250.

Calmfors, Lars, Anders Forslund, and Maria Hemström. (2004). "The Effects of Active Labour Market Policies in Sweden: What Is the Evidence?” In J. Agell, M.J. Keen and A.J. Weichenreider (eds.), Labor Market Institutions and Public $\underline{\text { Regulation, }}$ Cambridge, MA: MIT Press.

Cameron, D. R, (1978), “The Expansion of the Public Economy: A Comparative Analysis", American Political Science Review. 72, 1243-61.

Casella, A. (1999). “Tradable Deficit Rights: Efficient Implementation of the Stability Pact in the European Monetary Union”, Economic Policy 29, 323-361.

Cooper, Richard. (1968). The Economics of Interdependence, New York.

Dahlberg, Matz, and Anders Forslund. (2005). "Direct Displacement Effects of Labour Market Programmes: the Case of Sweden", Scandinavian Journal of Economics (forthcoming).

Engbersen, Godfied, et al. (1993). Cultures of Unemployment, Oxford: Westview Press.

Feenstra, Robert C., and Gordon H. Hansen. (2005). "Global Production Sharing and Rising Inequality: A Survey of Trade and Wages”. In Kwan Choi, and James Harrington (eds.), Handbook of International Trade, Oxford: Basil Blackwell. Gil Alonso, Fernando. (2005). "Building a Simplified Model to Assess the Impact of Population Ageing, Employment Trends and Immigration Levels on Pension 
Sustainability in the EU-25", mimeo, International Union for the Scientific Study of Population, Office of Population Research, Princeton University. Heckman, J. J. (1993). "What Has Been Learned About Labor Supply in the Past Twenty Years, American Economic Review, Papers and Proceedings, 83, 116121.

Heckman, J. J., R.J. Lalonde, and J.A.- Smith. (1999). "The Economics and Econometrics of Active Labor Market Programs”. In O. Ashenfelter, and D. Card (eds.), Handbook of Labor Economics, Vol. 3a, Amsterdam: NorthHolland.

Hesselius, Patrik, Per Johansson, and Laura Larsson. (2005). “Monitoring Sickness Insurance Claimants: Evidence from a Social Experiment”, Working Paper 2005:15, Institute for Labour Market Policy Evaluation, Uppsala, Sweden.

Jacobsen Kleven, H. and C. T. Kreiner. (2005). "The Marginal Costs of Public Funds: Hours of Work vs Labor Force Participation”, (Home page of Jacobsen Kleven, H,. Institute of Economics, University of Copenhagen)

Jones, Ron, and Henryk Kierzkowski. (2005). "International Fragmentation and the New Economic Geography", North American Journal of Economics and Finance, 16, 1-10.

Krueger, A. B., and B. D. Meyer. (2002). "Labor Supply Effects of Social Insurance”. In A. Auerbach, and M. Feldstein (eds.), Handbook of Public Economics 4, Amsterdam: North-Holland.

Lindbeck, Assar. (1978). "Economic Dependence and Interdependence in the Industrialized World". In Marshall Plan to Global Independence, Paris: OECD, 59-86. 
Lindbeck, Assar. (1980). “Tax Effects versus Budget Effects on Labor Supply”, Economic Inquiry, XX, 473-89.

Lindbeck, Assar. (1995). "Hazardous Welfare State Dynamics”, American Economic

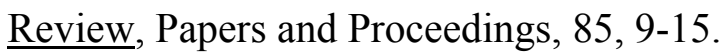

Lindbeck, Assar, and Dennis Snower. (1988). The Insider-Outsider Theory of Employment and Unemployment, Cambridge Mass.: MIT Press.

Lindbeck, Assar, Sten Nyberg, and Jörgen. W. Weibull. (1999). "Social Norms and Economic Incentives in the Welfare State", Quarterly Journal of Economics, $114(1), 1-35$.

Lindbeck, Assar, et al. (1994). Turning Sweden Around, Cambridge USA: MIT Press. Lindbeck, Assar, and Sten Nyberg. (2005). "Raising Children to Work Hard: Altruism, Work Norms and Social Insurance”, memo, IIES, Stockholm University, April.

Lindbeck, Assar, and Dirk Niepelt. (2005). "Improving the SGP: Taxes and Delegation Rather Than Fines”, CESifo Working Paper No. 1389, January. Lindbeck, Assar, Mårten Palme, and Mats Persson. (2004). "Sjukskrivning som ett socialt fenomen" ("Sickness Absence as a Social Phenomenon"), Ekonomisk Debatt, 32(4), 50-62.

Lindbeck, Assar, and Mats Persson. (2005).”A Model of Income Insurance and Social Norms", memo, Institute for International Economic Studies, University of Stockholm.

Ljungqvist, Lars, and Thomas Sargent. (2004). “The European Unemployment Dilemma", Journal of Political Economy, 106(3), 514-50. 
Marin, Dalia. (2004). “'A Nation of Poets and Thinkers' - Less So with Eastern Enlargement? Austria and Germany" Discussion Paper No 4358, March, CEPR.

Martin, John P., and David Grubb. (2001). "What Works and for Whom: A Review of OECD Countries' Experiences with Active Labour Market Policies”, $\underline{\text { Swedish }}$ Economic Policy Review, 8, 9-56.

Modig, A., and K. Broberg. (2002). “Är det OK att sjukskriva sig fast man inte är sjuk?" ("Is It OK to Take Sick Absence without Being Sick?”) Rapport T22785, Temo, Stockholm, Sweden.

Nickell, Stephen, Luca Nunziata, and Wolfgang Ochel. (2005). "Unemployment in the OECD Since the 1960s. What Do We Know?", The Economic Journal, $115,1-27$.

OECD. (2003). Employment Outlook, Paris: OECD.

OECD. (2004). Revenue Statistics 1965-2003, Paris: OECD.

OECD. (2005b). Trade and Structural Adjustment, Paris: OECD

OECD. (2005c). Society at a Glance: OECD Social Indicators, Paris: OECD.

Renstig, Monica, and Hélène Sandmark. (2005). “Kvinnors sjukskrivning” (Women's Sickness Absence”), memo, January, Stockholm: Karolinska Institutet RFV (Riksförsäkringsverket). (2005). Kunskaps- \& attitydstudie avs. sjukförsäkringen ('Knowledge and Attitude Study Concerning Sick-Pay Insurance"), study made by Refina Information AB for RFV.

Rodrik, D. (1998). "Why Do More Open Economies Have Bigger Governments?”, The Journal of Political Economy, 106, 997-1032. 
Sinn, Hans Werner. (1999).’Pension Reform and Demographic Crisis: Why a Funded System is Needed and Why It is Not Needed", CESifo Working Paper No 195, Munich.

Sinn, Hans Werner. (2004). Das Exporträtsel”, Suddeutsche Zeitung, October 29.

Skogman Thoursie, Peter. (2002). "Reporting Sick: Are Sporting Events Contagious?", Journal of Applied Econometrics, 19, 809-823.

Slaughter, Matthew J. (1999). "Globalization and Wages: A Tale of Two Perspectives", World Economy 22(5), 609-30.

Svenska Kommunförbundet. (2002). Kommunala framtider - en långtidsutredning om behov och resurser till 2050 (Futures for municipalities - a long term study on the need for resources until 2050), Stockholm: Svenska Kommunförbundet. 


\begin{abstract}
* I am grateful for useful comments on a draft of the paper from Mathias Herzing, Bertil Holmlund, Richard Murray, Torsten Persson, Hans-Werner Sinn, and Solveig Wikström.

${ }^{1}$ Social spending then includes old age, survivors, and disability cash benefit; occupational injury, disease and sickness benefits; services for the elderly and disabled; family cash benefits and family service; unemployment benefits and active labor market program; education; health care; housing benefits; and other contingencies.
\end{abstract}

${ }^{2}$ In principle, welfare-state arrangements may be regarded as "unsustainable" even if the intertemporal budget constraint is respected. I refer to the specific situation when the disincentive effects of social spending, and its financing, are so severe that economic efficiency, GDP growth or the employment level are harmed more than what citizens and/or politicians would have liked and are willing to accept. In other words, under certain circumstances, fiscal policy may be regarded as unsustainable even if politicians succeed in raising taxes (and fees of various types) sufficiently to avoid galloping government debt. The paper does not explicitly deal with this broader view of sustainability, which we may call "economic sustainability" (and include "fiscal sustainability" as a subset).

${ }^{3}$ During the last quarter of a century, per capita GDP has increased by a factor of 3 or 4 in several countries in South East Asia, including China.

${ }^{4}$ This prediction is not watertight. When particularly labor-intensive tasks are outsourced to low-wage countries, the costs of (imported) labor-intensive intermediary products fall, which will increase the marginal product and hence, the demand for low-skill workers in firms engaged in such outsourcing; see Ron Jones and Kierzkowski (2005).

${ }^{5}$ For a survey of the literature in this field, see Slaughter (1999). An often-quoted figure is that the predicted gross job destruction in the United States due to outsourcing to other countries (according to the most pessimistic forecasts) is less than one per cent $(0.71 \%)$ of the total gross destruction of jobs in the country during the last decade (OECD, 2005a and 2005b). However, a large part of these gross job losses reflect short-term fluctuations in the demand for labor, without any relation to long-term structural changes in the labor market. By contrast, there is evidence of a wider dispersion of wages, although less so on the European continent than in most other developed countries. There is, however, considerable controversy about the extent to which this is a result of globalization 
${ }^{6}$ According to OECD statistics (2004), property taxes constitute slightly less than five percent of the total tax revenues in EU.

${ }^{7}$ According to a calculation by the Swedish Association of Local Authorities (Svenska Kommunförbundet, 2002), a constant fraction between human services (provided by municipalities) and total consumption would require yearly changes in the municipal income tax by $0.35-0.4$ percentage points, resulting in predicted municipal income tax rates of 50 percent in the year 2050 just to finance human services.

${ }^{8}$ Historically, the production costs for human services have been kept down by relatively low wages for females - a period that is certainly coming to an end.

${ }^{9}$ So far, a rapid increase in transfer payments in developed countries in recent decades has, however, often squeezed out both the provision of human services and "classical" tasks of the state, such as crime prevention and military defense.

${ }^{10}$ Indeed, in the special case when the production share (of GDP) of human services is kept constant, a further rise in the rate of productivity growth in other sectors would make it necessary to raise the tax rate even more quickly (in the context of the simple model referred to above). The intuition is that labor must now be reallocated to the tax-financed sector from other sectors; see the Appendix.

${ }^{11}$ To some extent, the situation is the same in the "health-care part" of old-age care, although the purely medical part of services is smaller in this case than in ordinary health care.

${ }^{12}$ The OECD secretariat predicts that "old-age dependency" (the population aged 65 and above as a percentage of the population aged 15-64) in EU-19 will increase from about 23 to about 50 per cent between 2005 and 2050 (OECD, 2000c). If the age-dependency rate is instead defined as the number of actually retired individuals per 100 actually employed (in full-time equivalents), the rate would be 55 for EU-19 today, and has in one quite ambitious study been hypothetically calculated to increase to 90 in the year 2050 - assuming a constant effective retirement age of 61 years, and a continuation of recent trends in demography and net immigration (Gil Alonso, 2005).

${ }^{13}$ This problem would be avoided if the real value of benefits were strictly tied to real wages (and hence, labor productivity).

${ }^{14}$ In the international literature, such a system has recently been baptized notional defined-contribution (NDC) systems. Alko et al. (2005) use stochastic population stimulations to show how demographic 
risks in the context of pension systems are shifted across and within generations in the context of fixed rules.

${ }^{15}$ Some such adjustments in response to changes in real wage growth, although often with long time lags, do, however, sometimes exist in paygo social insurance systems.

${ }^{16}$ I use the term "equilibrium unemployment" in its traditional sense: the rate of unemployment below which inflation tends to increase.

${ }^{17}$ A number of persistence mechanisms have been identified in the literature; see, for instance, Lindbeck and Snower (1988). Ljungqvist and Sargent (2004) and Blanchard and Wolfers (2000) have suggested that the high unemployment persistence in Western Europe is the result of asserted shifts in the composition of skills demanded in the labor market.

Moreover, it is not difficult to identify relevant unemployment-creating macroeconomic shocks in Western Europe: the oil-price shocks in 1973 and 1980 and the deflationary policies in the first half of the 1980s and in the 1990s, designed to bring down high and often rising inflation and galloping budget deficits.

${ }^{18}$ Such benefits may be regarded as a negative income tax confined to the "working poor".

${ }^{19}$ There is a "back-side" of selective in-work benefits and employment subsidies, in the sense that jobs for others are crowded out. The number of crowded out jobs often seems to be between half and three quarters of the gross number of jobs created by the subsidies. See Heckman, Lalonde and Smith (1999); Martin and Grubb (2001); Calmfors, Forslund and Hemström, (2004); and Dahlberg and Forslund, (2005) Most of these studies only cover "directly" crowded out jobs (calculated at fixed real wage rates).

${ }^{20}$ The view that demand management influences aggregate employment, at least during some period of time of course usually builds on the (realistic) assumption that prices do not immediately adjust in proportion to variations in aggregate demand

${ }^{21}$ If the tax revenues are instead used to finance benefits to individuals of working age, the positive income effects of higher taxes will be counteracted by negative income effects of the benefits. ${ }^{22}$ The explicit marginal tax rates are often in the interval of 40-60 percent for a majority of citizens in Western Europe, when all types of taxes on households are included - income taxes, sales taxes, value added taxes, and the "pure" tax elements of the payroll tax that finance social insurance benefits, as 
well as the implicit tax rates when income-dependent benefits are gradually reduced by higher income.

(OECD statistics.)

${ }^{23}$ For instance, when taking account of adjustments also on the extensive margin, Kleven and Kreiner (2005) estimate, conservatively, the marginal costs of public funds in countries on the European continent to the interval of 1.2 to 2.2 euros for every euro of additional tax revenues. Usual estimates of the marginal deadweight costs of higher taxes as a result of adjustments of labor supply on the intensive margin (in high-tax countries) hover in the interval of .1-.3 euros for every euro of increased tax revenues.

${ }^{24}$ Defined as the ratio between disposable incomes when living on benefits and when working. ${ }^{25}$ According to a sampling study in Sweden (Renstig and Sandmark, 2005), most women do not get more than about 100-200 dollars more per month when working than when living on social-insurance benefits. Indeed, if the costs of working (transportation and extra costs for lunches) are deducted from earnings, 90 percent of the women in the sample will get a lower disposable income from work than from living on social-insurance benefits.

${ }^{26}$ An exception is that unemployment benefits gradually became more generous in some countries up until the early 1980s (Nickel et al., 2005).

${ }^{27}$ According to an attitude study by Modig and Broberg (2002), nearly half of the individuals asked said that it is OK to take sickness absence without being sick: for instance, when having problems in the family, experiencing a bad work environment or feeling stress at work. More than a fifth believe that it is OK to do so if disliking their job or having a "bad" boss. Two studies for the Swedish Social Insurance Board by Refina Information AB for 2004 and 2005 (RFV, 2005) have given basically the same results.

More indirect evidence is that a considerable number of individuals report being fit to return to work exactly at the time (today after 6 days) when a doctor's certificate is required in the sick-pay system (Hesselius et al. (2005). The latter result reminds us of the observation that a large number of unemployed individuals in the US suddenly get jobs exactly when the unemployment benefits expire. ${ }^{28}$ For instance, Skogman Thoursie (2002) reports a rise by 16 percent in the sickness absence of men in Sweden during the Winter Olympic Games in the mid-1990. Some employees have also, via concerted action, called in sick to exert pressure on the employer in connection with wage bargaining. 
${ }^{29}$ For instance, it has turned out to be impossible to explain the large differences in sickness absence across Swedish municipalities by differences in measurable variables, such as working conditions, or personal or socio-economic factors. In a study using ten different types of explanatory variables (several of which consist of a number of dummy variables) to explain sickness absence, there turns out to be an unexplained difference of up to 60 days in a year of sickness absence between municipalities with a minimum and a maximum number of sickness absence days (Lindbeck, Palme, and Persson, 2004).

${ }^{30}$ A study in Sweden, which may be regarded as a "natural experiment", concluded that the requirement of a physician's certificate from day three, instead of day ten, would reduce the sickness absence by about ten percent (Hesselius et al., 2005).

${ }^{31}$ In the case of unemployment benefits, the authorities have recently extended the test of applicants' willingness to work by offers of tax-financed public-sector jobs. One problem with such controls is, of course, that private firms will then be discriminated against and jobs in that sector will, in fact, be crowded out. While general subsidies of wage costs for unemployed workers avoid such discrimination, they are bound to crowd out non-subsidized (private and public-sector) jobs.

${ }^{32}$ In 2004 and 2005, the Swedish authorities apparently believed this to be possible, since they tried to convince citizens, by way of advertisement campaigns, that it is unacceptable behavior to "call in sick" (sjukskriva sig) without being sick. (These campaigns have not only been directed at applicants, and potential applicants for sick pay, but also at physicians and administrators of the government-operated sickness insurance system.) After the start of the campaign, sickness absence has started to fall, although it is not clear to what extent this is the result of the attempts to influence the norms or of the application of a stricter administration of the system than earlier.

${ }^{33}$ Such reforms were suggested in a Swedish context by a government-appointed expert group in 1993 (Lindbeck et al., 1994).

${ }^{34}$ Such rules may be motivated either to fight undesired international spillovers of domestic budgets, or to deal with domestic policy failures extending to the constitutional level, in the sense that individual countries are not themselves able to create rules that guarantee sustainability.

${ }^{35}$ An alternative, trade in deficit permits, has been suggested by Casella (1999). Pigouvian taxes seem easier to implement, however. 
${ }^{36}$ As a result, these countries have experienced a gradual reduction in the GDP share of central government debt from about the early 1990s - in the UK even earlier (OECD statistical data base: Central Government Debt. 